\title{
Degree of damage and infestation of coconut leaf beetle Brontispa longissima (Gestro) on seedlings of selected coconut varieties
}

\author{
Gladys R. Cabelin ${ }^{1 *}$ and Maria Juliet C. Ceniza ${ }^{2}$
}

The Coconut Leaf Beetle, scientifically known as Brontispa longissima (Gestro), is an introduced species that is becoming an alarming pest of coconuts in the Philippines. The infestation caused by this pest is considered to be damaging to all stages of coconut growth. This study was conducted to assess the degree of damage and infestation caused by Brontispa longissima on the seedlings of 10 selected tall and dwarf coconut varieties in the National Coconut Research Center at Visayas State University, Leyte, Philippines. Among the selected varieties, seedlings of Baybay Tall (green and brown) and Albuera Dwarf varieties succumbed to more damage by $B$. longissima beetles compared with the other varieties observed with $41-80 \%$ of the first openned leaf area damaged. Seedlings of Malayan Yellow Dwarf and Malayan Red Dwarf varieties had the least damage with $0-20 \%$ of the first openned leaf area damaged. The high damage ratings of Baybay Tall and Albuera Dwarf were expected because these varieties had high infestation rates and harbored the most numbers of $B$. longissima adults, eggs, and larval stages, which indicated the preference of $B$. longissima for these varieties. The developmental period of $B$. longissima in Baybay Tall and Albuera Dwarf of 44 days and 45 days on the average, respectively, was shorter than in other varieties, indicating that these are suitable and preferred hosts. Baybay Tall seemed to be the most preferred variety. The beetles had least preference for Malayan Yellow Dwarf and Malayan Red Dwarf varieties.

Keywords: $B$. longissima, coconut varieties, BAYT variety, preference

${ }^{1}$ Agriculture Department, College of Agriculture and Natural Resources Bohol Island State University 2Department of Plant Protection, College of Agriculture and Food Science Visayas State University

*Corresponding Author. Address: Agriculture Department, College of Agriculture and Natural Resources Bohol Island State University; Email: rosalesgladysb@gmail.com 


\section{INTRODUCTION}

The Coconut Leaf Beetle (CLB), scientifically known as Brontispa longissima (Gestro), is an introduced species that is becoming an alarming pest of coconuts in the Philippines. The infestation caused by this pest is considered to be damaging to all stages of coconuts, as well as a range of ornamental palm species. Both larvae and adults of $B$. longissima infest the developing, unopened coconut fronds as they emerge from the heart. When the leaf opens, it quickly dries out and the leaf tissues die. Damage ranges from severe, heavy, moderate to light-moderate. Severe infestation by the beetle can cause complete defoliation of the palm and, if prolonged, will result in the death of the palm. Brontispa has become an increasingly serious pest of coconuts throughout various growing regions in the Pacific, especially over the last 3 decades, leading to significant production losses (Guo 2005). This pest can attack up to 17 species of palms including oil palm, betel palm, nipa palm, and several ornamentals (Wilco et al 2004).

In the Philippines, the coconut industry is the second most important agricultural sector in terms of the planted area, the number of dependents, and the share of agricultural exports. Production is generally concentrated on medium-sized farms (FAO 2009). It is also among the country's top ten export products as exhibited by the good export performance of both traditional and non-traditional coconut products. About one-third of the country's arable agricultural land or 3.26 million hectares are planted to coconut, representing 64 out of a total 79 provinces and 1,195 out of the 1,554 municipalities in the country. It provides a sustainable income source for Filipinos by way of employment generation assisted by many government programs. (https://www.bar.gov.ph/index.php/agfishtech-home/crops/206-plantationcrops/1279-coconut).

Although the pest has been known to infest almost all the coconut palms, notwithstanding the stage, there have been no specific reports about the severity of the damage to various coconut varieties planted in the Philippines. There are many varieties of coconuts for farmers to choose from and selection will be based on the farmers' needs. However, there are two recognized types of coconut varieties, the dwarf and the tall varieties, distinguished according to height. Dwarf coconuts are usually early maturing (3-4 years) and produce nuts during their earlier years compared to the tall varieties (5-7 years). However, tall varieties are known to yield more nuts than dwarf varieties.

Eastern Visayas (Region VIII) is an agricultural region with coconuts as the major crops. Baybay Tall (BAYT), an outstanding tall coconut cultivar first discovered in Leyte, which was observed to have a much higher yield than the other known tall coconut varieties in the Philippines. It is regarded as comparable to some outstanding Philippine Coconut Authority (PCA) DxT hybrids (Rivera et al 2011) and recommended by PCA for the national coconut replanting program together with the outstanding PCA hybrids.

However, tall and dwarf coconut varieties have not been assessed as to their vulnerability or tolerance to damage by the Brontispa beetles in the country. Reports from some countries showed that different coconut varieties vary considerably in their susceptibility to Brontispa attack. For example, a variety called Rennell of the Solomon Islands was scarcely attacked. In contrast, varieties from Malaysia such as FMS (Federated Malay States) and dwarf red and yellow palms are highly 
susceptible. The susceptibility of Malaysian dwarfs is carried into their hybrids. On the other hand, some Ivory Coast and Fiji varieties show high degrees of resistance (Stapley 1980a, 1981). Of the six local coconut cultivars tested in Western Samoa, five were highly susceptible, and the green dwarf was fairly resistant (FAO 2004).

Over the years, the National Coconut Research Center-Visayas, located at the Visayas State University (VSU) campus, has accumulated several coconut varieties grown in its gene bank and has carried out characterization studies of the different tall and dwarf varieties collected for several decades. Some of these varieties have been selected and recommended and thus were planted in demo farms outside of VSU.

This study, therefore, aimed to assess the degree of Brontispa infestation on the different selected and recommended varieties. It also aimed to determine the degree or severity of the damage caused by the beetles at the seedling stage of the coconut. The study also investigated the effect on the biology and development of the CLB when reared on the different tall and dwarf varieties under field condition.

\section{MATERIALS AND METHODS}

\section{Establishment of Sampling Site and Sample Seedlings in the Nursery}

Ten recommended coconut varieties of the National Coconut Research Center (NCRC) and Philippine Coconut Authority (PCA) of Region 8 were selected and used in this study, namely; Baybay Tall (BAYT-green), Baybay Tall (BAYT-brown), Sogod Dwarf (SGD), Tacunan Dwarf (TACD), Coconiño Dwarf (COD), Albuera Dwarf (ALD), Camotes Dwarf (CAMD), Catigan Dwarf (CATD), Malayan Red Dwarf (MRD), Malayan Yellow Dwarf (MYD). These seedlings were selected because of their availability in the NCRC gene bank and the Coconut-Hybridization area.
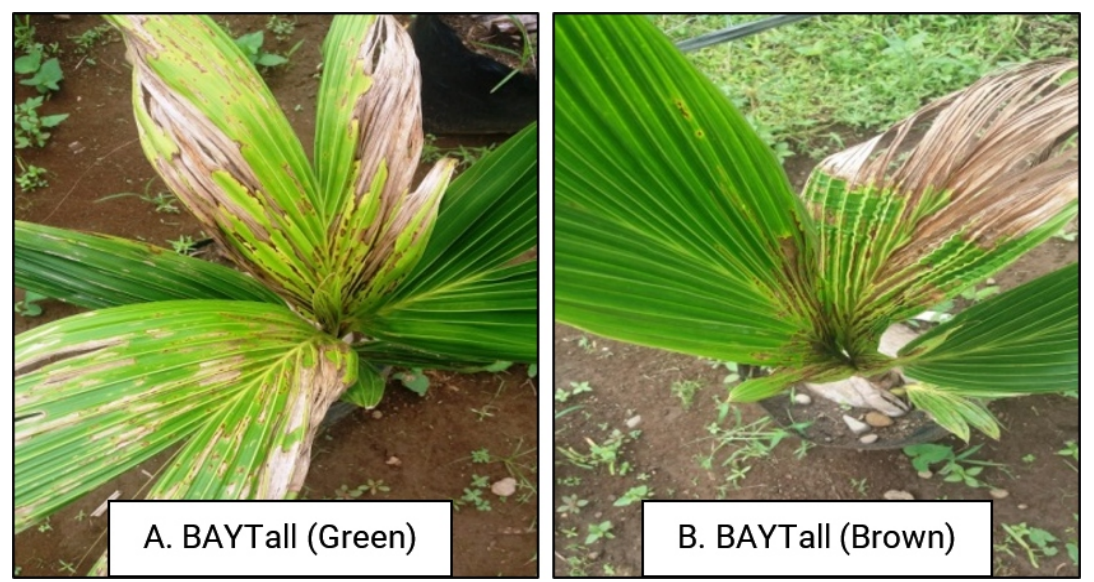

Figure 1. Seedlings of A.) BAYT (green), B.) BAYT (brown) C.) SGD, D.) TACD, E.) CÑOD, F.) CAMD, G.) ALD, H.) CATD, I.) MYD and J.) MRD showing the degrees of damage caused by $B$. longissima (Gestro) 

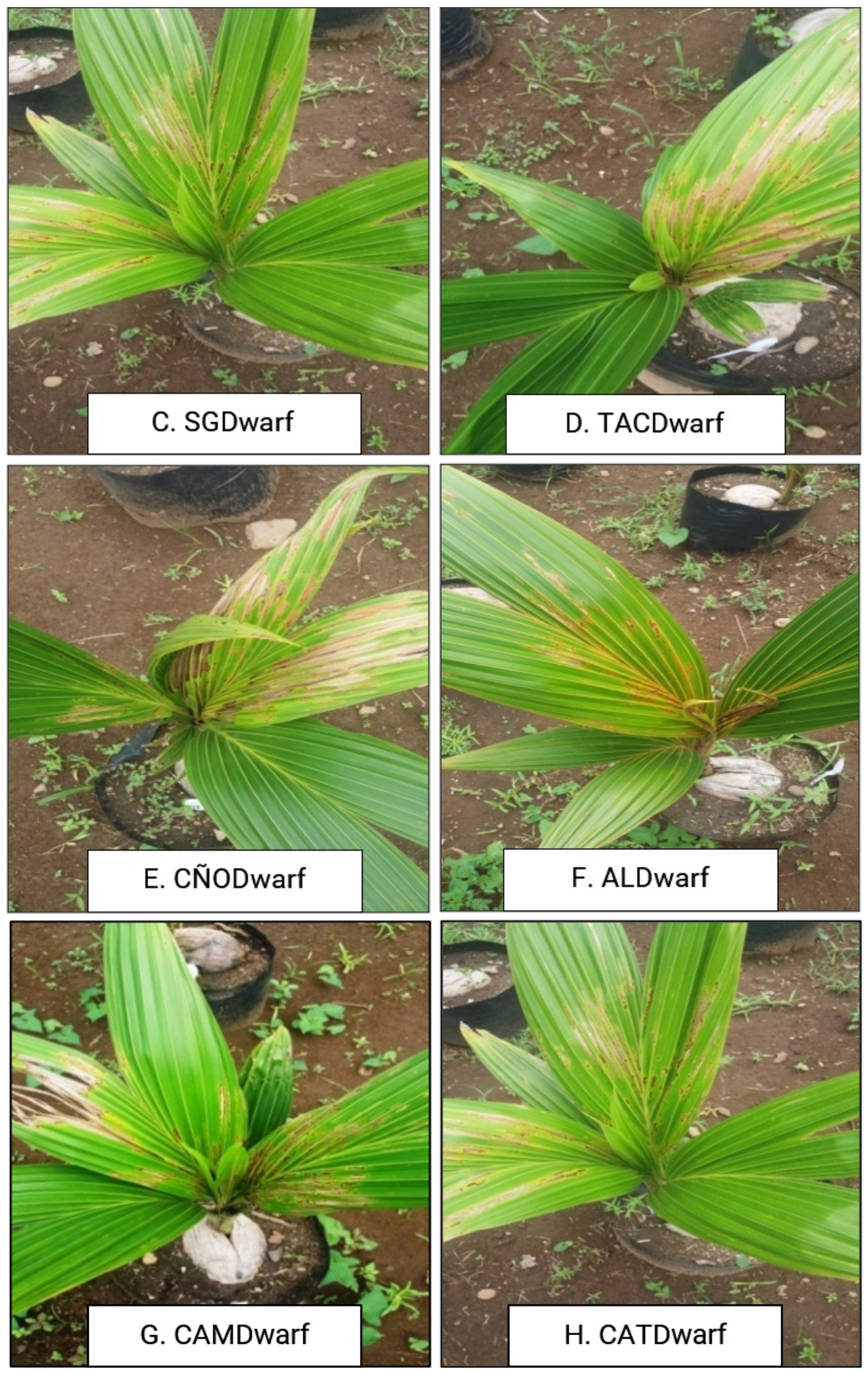

Figure 1 continued 

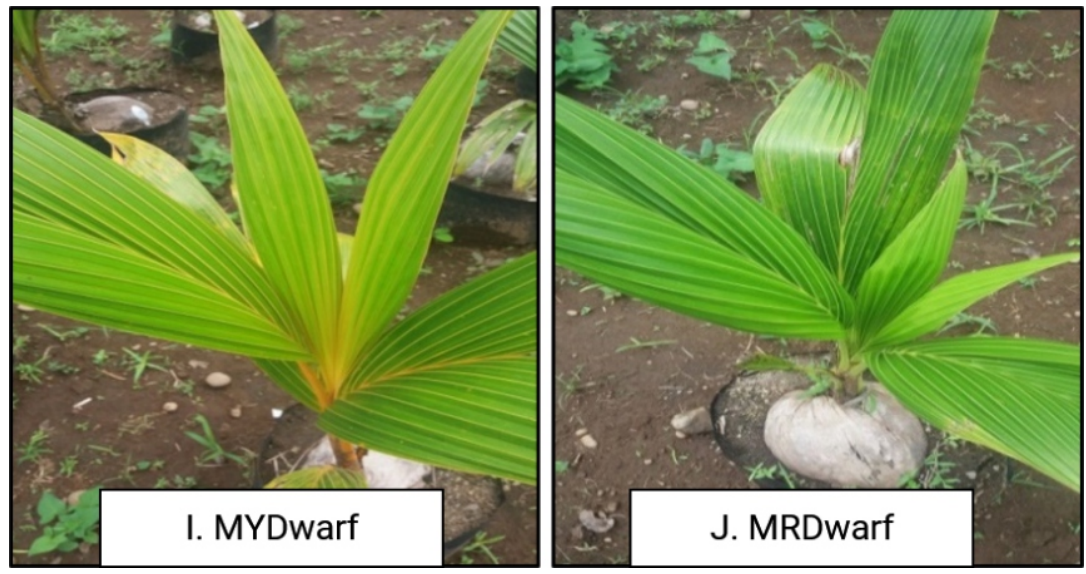

Figure 1 continued

\section{Preparation and Maintenance of Coconut Seedlings}

For the experiment, three-month-old $B$. longissima-free seedlings of these coconut varieties were obtained from the NCRC-Coconut Hybridization Area located at Brgy. Pangasugan, Baybay City, Leyte, Philippines. Nine seedlings per variety were used, or a total of 90 seedlings composed of ten varieties were procured for the experiment. Each seedling was placed individually in a polyethylene bag $(45.7 \times 40.64 \times 0.00152 \mathrm{~cm})$ with soil. The bottom of the polybags were perforated with holes to drain extra water and to prevent rotting of the roots. These seedlings were maintained inside NCRC nursery until they were ready for use in the experiment. Weeds on the pots and in the field were removed and the seedlings were watered every day. Recommended coconut seedling maintenance and monitoring was followed to avoid infestation prior to the experiment.

Table 1. Damage ratings of selected/recommended coconut variety seedlings caused by $B$. longissima under natural infestation in NCRC open field ${ }^{1 /}$

\begin{tabular}{lc}
\hline Varieties & Damage rating \\
\hline V1 - BAYT -Green & $4.67^{\mathrm{a}}$ \\
V2 - BAYT -Brown & $4.33^{\mathrm{a}}$ \\
V3 - SGDwarf & $1.67^{\mathrm{cd}}$ \\
V4 -TACDwarf & $200^{\mathrm{bcd}}$ \\
V5 - CÑODwarf & $2.67^{\mathrm{bc}}$ \\
V6 - ALDwarf & $3.33^{\mathrm{ab}}$ \\
V7 - CAMDwarf & $2.00^{\mathrm{bod}}$ \\
V8 - CATDwarf & $1.33^{\mathrm{cd}}$ \\
V9 - MRDwarf & $1.00^{\mathrm{d}}$ \\
V10 - MYDwarf & $1.00^{\mathrm{d}}$
\end{tabular}

1 / Mean of 3 replicates

Means followed by the same letter are not significant at $5 \%$ level, Tukey's HSD 


\section{Brontispa infestation}

The experiment was conducted in an open field where there was a natural source of $B$. longissima infestation. Ten varieties of coconuts were used. Each variety was replicated three times with three sample seedlings per replication. Each replicate was randomly set-up in a block with a distance of $0.5 \mathrm{mx} 0.5 \mathrm{~m}$ between seedlings and $1 \mathrm{~m}$ between blocks. There were three blocks in the area where each block represents one replication, with 30 seedlings per block. A total of 90 potted seedlings were used in the experiment. Collection of data on $B$. longissima infestation on the seedlings was done one day after field exposure. The seedlings were observed by checking and monitoring the number of eggs laid by the $B$. longissima daily. Thereafter, the number of larvae that hatched were counted. Daily observations were made to check the development of the pest on each seedling and the varietal reaction to the pest.

Rating of damage by beetles was done on every first opened frond of the seedlings. Estimated leaf area damage due to Brontispa beetles infestation was rated following Chin and Brown's established rating scale (2001) below.

\begin{tabular}{cc}
\hline Rating & Beetle damage to the first opened frond $(\%)$ \\
\hline 1 & $0-20 \%$ of the leaf area damaged by the beetle \\
2 & $21-40 \%$ of the leaf area damaged by the beetle \\
3 & $41-60 \%$ of the leaf area damaged by the beetle \\
4 & $61-80 \%$ of the leaf area damaged by the beetle \\
5 & $81-100 \%$ of the leaf area damaged by the beetle \\
\hline
\end{tabular}

The duration of development (in days) from egg to adult emergence was monitored for all the seedling varieties. Mortality of the different stages of $B$. longissima was also noted.

\section{RESULTS AND DISCUSSION}

\section{Assessment of Brontispa Beetle Damage and Infestation on Seedlings of Selected Coconut Varieties}

One of the physiological responses of the crop variety to a pest could be seen in its effect on the total development of the insect pest. However, it is also hypothesized that the observed variability in the damage to the crop could be brought about by the variability of the $B$. longissima population. Thus variability in insects' responses to plants/cultivars can lead to the possible emergence of a population that can overcome resistance by plants. The presence of a pest infestation on a crop triggers a corresponding response to it, either physiologically or metabolically (Tabugo et al 2012). 
Adults. Table 2 shows the average adult count of $B$. longissima on ten selected coconut varieties. BAYT (green) variety had the highest number of adults of Brontispa (M=5.00 adults) followed by BAYT brown, ALD, CND, TACD, CAMD, CATD, MRD, and MYD. Statistically, the number of adults infesting BAYT(green) variety was significantly higher than SGD, CND, TACD, CAMD, CATD, MRD, and MYD but with no significant differences with other varieties BAYT (brown) and ALD. On the other hand, among the dwarf varieties, ALD got the highest number of adults $(M=3.00)$ which was significantly different from the other dwarf varieties.

The above results indicate that $B$. longissima beetle preferred seedlings of BAYT green variety over other varieties. The exact factors that influenced the attractiveness of this variety to the beetle, was not investigated in this study. However, it is possible that since BAYT is a common variety planted in the area, chemical cues from this variety would likely play a significant factor in its becoming a preferred host.

Eggs. From the results presented in Table $2 \mathrm{~B}$. longissima egg counts were also found to be abundant in BAYT green (mean of 8.00) which was significantly different from SGD, TACD, CÑOD, CAMD, CATD, MRD, and MYD, but not significantly different from the BAYT brown and ALD varieties. On the other hand, the MYD variety had the least number of eggs counted, which was significantly different from BAYT green and brown and ALD, but not significantly different from the rest of the varieties. Among the dwarf varieties, Albuera Dwarf harbored more eggs $(M=4.67)$ compared to other dwarf varieties.

Larvae. Table 2 also shows the trend of $B$. longissima larva in ten selected varieties. BAYT green variety consistently had the highest larval count $(M=6.33)$ followed by BAYT brown, ALD, CÑOD, CAMD, CATD, TACD, SGD, MRD, and MYD. This was expected because it was also observed that there was a consistently high number of adults infesting BAYT green resulting in a high number of eggs and many larvae. However, analysis of the results suggests that the mean abundance of larvae on BAYT green was not significantly different from the BAYT brown and the Albuera Dwarf but was significantly different from the other varieties.

Table 2. Average count of adults, eggs, larvae and pupae of $B$. longissima in ten selected coconut varieties under field conditions. ${ }^{1}$

\begin{tabular}{lllll}
\hline \multirow{2}{*}{ Varieties } & \multicolumn{4}{c}{ Developmental Stages } \\
\cline { 2 - 5 } & Adult & Egg & Larva & Pupa \\
\hline V1 - BAYT -(green) & $5.00^{\mathrm{a}}$ & $8.00^{\mathrm{a}}$ & $6.33^{\mathrm{a}}$ & $6.00^{\mathrm{a}}$ \\
V2 - BAYT -(brown) & $4.33^{\mathrm{ab}}$ & $6.00^{\mathrm{ab}}$ & $4.67^{\mathrm{ab}}$ & $4.67^{\mathrm{ab}}$ \\
V3 - SGDwarf & $1.33^{\mathrm{cd}}$ & $1.33^{\mathrm{cd}}$ & $1.00^{\mathrm{cd}}$ & $0.00^{\mathrm{d}}$ \\
V4 - TACDwarf & $1.67^{\mathrm{cd}}$ & $1.33^{\mathrm{cd}}$ & $1.33^{\mathrm{cd}}$ & $1.00^{\mathrm{cd}}$ \\
V5 - CÑODwarf & $2.33^{\mathrm{bcd}}$ & $2.67^{\mathrm{bcd}}$ & $2.33^{\mathrm{bcd}}$ & $2.00^{\mathrm{cd}}$ \\
V6 - ALDwarf & $3.00^{\mathrm{abc}}$ & $4.67^{\mathrm{abc}}$ & $3.67^{\mathrm{abc}}$ & $3.33^{\mathrm{ab}}$ \\
V7 - CAMDwarf & $1.33^{\mathrm{cd}}$ & $1.33^{\mathrm{cd}}$ & $1.33^{\mathrm{cd}}$ & $1.33^{\mathrm{cd}}$ \\
V8 - CATDwarf & $1.33^{\mathrm{cd}}$ & $1.33^{\mathrm{cd}}$ & $1.33^{\mathrm{cd}}$ & $1.00^{\mathrm{cd}}$ \\
V9 - MRDwarf & $0.67^{\mathrm{d}}$ & $1.00^{\mathrm{cd}}$ & $0.67^{\mathrm{d}}$ & $0.00^{\mathrm{d}}$ \\
V10 - MYDwarf & $0.67^{\mathrm{d}}$ & $0.67^{\mathrm{d}}$ & $0.67^{\mathrm{d}}$ & $0.00^{\mathrm{d}}$ \\
\hline
\end{tabular}

$1 /$ Mean of 3 replicates

Means followed by the same letter are not significant at $5 \%$ level, Tukey's HSD 
Pupae. A similar trend was also obtained in terms of the number of pupae on selected coconut varieties. Consistently, BAYT green obtained the highest pupal counts $(M=6.00)$ which were significantly different from other varieties but not with BAYT brown. On the other hand, no pupa was observed during the pupal stage in MYD, MRD, and SGD which means the larvae in MYD, MRD, and SGD did not undergo pupation. This might be due to some factors such as physiological factors and the effect of the host plant. However, it cannot be denied that environmental factors can also affect the development of the beetle in the host plant. Since in this experiment all the varieties tested were exposed to the same environmental conditions, the effect of the palm variety on the beetle may have been a major factor that affected larval development up to the pupal period.

Generally, the results indicated a higher number of adults, egg, larva, and pupa of $B$. longissima on both BAYT green and brown compared to other varieties. This result would confirm the high preference of the beetle for Baybay Tall varieties compared to other varieties. The more adults that are present would result in a higher number of eggs, as was observed in Baybay Tall green and brown varieties. This host preference of $B$. longissima for Baybay Tall maybe due to the condition that the central shoot of this tall variety opens slowly and the leaflets remain closed for a longer period than other varieties. These characteristics would provide a suitable environment and habitat for the productive breeding of B.longissima. For Dwarf varieties, on the other hand, the shorter interval between the opening of successive fronds of coconut and their size, would contribute greatly to their relative freedom from attack (ASEAN IPM 2007, PestNet 2002). However, environmental factors are also seen as likely determinants of host specificity (Sandstrom and Peterson 1994, Schoonhoven et al 2005).

Table 3 shows the developmental period of $B$. longissima in different coconut varieties under field conditions. The Baybay Tall variety provided the most suitable host plant condition as shown by the difference in the total developmental period among the different varieties. The results showed that the development of the Brontispa beetles was shorter in the preferred varieties (BAYTgreen $=43$ days) and BAYTbrown=44 days) than the rest of the varieties observed. From published reports (Liu et al 2011), it has been recognized that suitable hosts will give shorter developmental periods for insects and the highest survival and fecundity. In Table 3 , it can be seen that the preferred BAYT varieties consistently had numerous adults, eggs, and larvae developing compared to the other varieties studied. The short duration of the developmental period also confirmed the beetles' host preference for the BAYT varieties.

Table 3. Duration (in days) of the developmental stages of Brontispa longisssima (Gestro) reared on selected coconut varieties under field conditions

\begin{tabular}{lcccc}
\hline Coconut Varieties & $\begin{array}{c}\text { Incubation } \\
\text { Period }\end{array}$ & $\begin{array}{c}\text { Total Larval } \\
\text { Period }\end{array}$ & $\begin{array}{c}\text { Pupal } \\
\text { Period }\end{array}$ & $\begin{array}{c}\text { Total } \\
\text { Development }\end{array}$ \\
\hline V1- BAYT ( green) & 4.00 & 32.6 & 4.66 & 42.66 \\
V2-BAYT (brown) & 4.00 & 33 & 5.00 & 43.66 \\
V3-SGDwarf & 4.66 & 35 & $*$ & $*$ \\
\hline
\end{tabular}


Degree of damage and infestation of coconut leaf beetle

Table 3 continued

\begin{tabular}{lcccc}
\hline Coconut Varieties & $\begin{array}{c}\text { Incubation } \\
\text { Period }\end{array}$ & $\begin{array}{c}\text { Total Larval } \\
\text { Period }\end{array}$ & $\begin{array}{c}\text { Pupal } \\
\text { Period }\end{array}$ & $\begin{array}{c}\text { Total } \\
\text { Development }\end{array}$ \\
\hline V4-TACDwarf & 5.00 & 36 & 5.50 & 48.5 \\
V5-CÑODwarf & 5.00 & 35.33 & 5.50 & 48.33 \\
V6-ALDwarf & 4.66 & 34.66 & 5.00 & 45.33 \\
V7-CAMDwarf & 5.00 & 35 & 4.33 & 46.33 \\
V8-CATDwarf & 4.66 & 36 & 5.00 & 47 \\
V9-MRDwarf & 5.00 & 38 & $*$ & $*$ \\
V10-MYDwarf & 5.00 & 39 & $*$ & \\
\hline
\end{tabular}

*no pupa emerged

\section{CONCLUSION AND RECOMMENDATION}

Baybay Tall (BAYT) green and brown varieties succumbed to more damage by B. longissima beetles while the Malayan Yellow Dwarf (MYD) and Malayan Red Dwarf (MRD) had the least damage. Among the dwarf varieties, ALD, with a damage rating of 3.33 , was more vulnerable to the $B$. longissima beetles than the other dwarf varieties. $B$. longissima beetle eggs, larvae, pupae, and adults were more abundant on BAYT green and brown varieties compared to the other varieties under field conditions. A longer and more thorough study on the varietal reactions to $B$. longissima beetle is recommended to establish the reactions of the different recommended coconut varieties to the $B$. longissima beetle.

\section{ACKNOWLEDGMENT}

The authors would like to thank the Department of Science and Technology Science Education Institute (DOST-SEI) Accelerated Science and Technology Human Resource Development Program (ASTHRDP) for funding support.

\section{REFERENCES}

Asean IPM Knowledge Network Management. 2007. The coconut leaf bettle, Brontispa longissima (Gestro). www.aseanipm.da.gov. gh/brontispa.htm

Chin D and Brown H. 2001. Biological control of palm leaf beetle, Brontispa longissima Gesto (Coleoptera: Chrysomelidae) with the wasp parasitoid, Tetrastichus brontispae (Ferriere) (Hymenoptera: Eulophidae) in Darwin. Proceedings of the sixth workshop for tropical agricultural entomology, Darwin, Australia, 11-15 May 1998. Technical Bulletin Department of Primary Industry and Fisheries, Northern Territory of Australia, No. 288 
FAO (Food and Agriculture Organization of the United Nations). 2004. Report of the expert consultation on coconut beetle outbreak in APPPC member countries, 26-27 October 2004. Bangkok, Thailand, Food and Agriculture Organization of the United Nations Regional Office for Asia and the Pacific

FAO (Food and Agriculture Organization of the United Nations). 2009. Developing an Asia-Pacific strategy for forest invasive species: the coconut beetle problem bridging agriculture and forestry. Report of Asia-Pacific Forest Invasive Species Network Workshop

Guo J. 2005. Coconut beetle management in Hainan Island, China: assessment of issues, new developments and future plans. In developing an asia-pacific startegies for forest invasive species. In Appanah S, Sim HC \& Sankaran KV (eds) Developing an Asia-Pacific Strategy for Forest Species: The Coconut Leaf Beetle-Bridging Agriculture and Forestry. Food and Agriculture Organization of the United Nations Regional Office for Asia and the Pacific, Bangkok

Liu YQ, Chu-Yan Z, Yang L, Yong-Long Z \& Ting-Ting L. 2011. Evaluation of insecticidal activity of podophyllotoxin derivatives against Brontispa longissima. Pesticide Biochemistry and Physiology 99(1):39-44

Rivera RL, Santos GA, Rivera SM, Emmanuel EE \& Baylon GB. 2011. Development of synthetic variety of coconut: PCA Syn Var 001 I. status and prospects. Coconut Research \& Development (CORD) 24(1):90-112

Sandstrom J and Petersson J. 1994. Amino acid composition of phloem sap and the relation to intraspecific variation in pea aphid (Acyrthosiphon pisum) performance. Journal of Insect Physiology 40(11):947-955

Schoonhoven LM, Van Loon JJA \& Dicke M. 2005. Insect-Plant Biology. Oxford University Press, Oxford, UK

Stapley JH. 1980a. Coconut leaf beetle (Brontispa) in the Solomons. Alafua Agricultural Bulletin 5(4):17-22

Stapley JH. 1980b. Using the predatory ant, Oecophylla smaragdina, to control insect pests of coconuts and cocoa. Information Circular, South Pacific Commission No. 85

Tabugo SRM, Torres MAJ, Olowa LF, Sabaduquia MAB, Macapil RM, Acevedo AM \& Demayo CG. 2012. Elliptic fourier analysis in describing shape of the mandible of the larvae of the coconut leaf beetle Brontispa longissima Gestro,1885 (Chrysomelidae: Hispinae) collected from plants with varying degrees of damage. International Research Journal of Biological Sciences 1(8):19-26

Wilco L and Chapman K. 2004. Impact and control of the coconut Hispine beetle, Brontispa longissima Gestro (Coleoptera: Chrysomelidae). Report of the expert consultation on coconut beetle outbreak in APPPC member countries. Bangkok, Thailand:FAO RAP Publication 2004/29 